\title{
BIODIESEL SYNTHESIS FROM THE USED COOKING OIL USING CaO CATALYST DERIVED FROM WASTE ANIMAL BONES
}

\author{
Luqman Buchori $^{1}{ }^{凶}$, Didi Dwi Anggoro ${ }^{1}$, Anwar Ma'ruf ${ }^{2}$
}

https://doi.org/10.23939/chcht15.04.583

\begin{abstract}
The synthesis of biodiesel from the used cooking oil with $\mathrm{CaO}$ catalyst from waste animal bones has been investigated. The content of free fatty acids (FFA) in the used cooking oil was reduced by adsorption using activated charcoal from a salak peel. Biodiesel synthesis was carried out via transesterification using $\mathrm{CaO}$ catalyst. The $\mathrm{CaO}$ catalyst was obtained from waste animal bones calcined in the Ney Vulcan furnace. The effect of calcination temperature was studied in the range of $873-1273 \mathrm{~K}$. The effect of catalyst loading was investigated by varying within the range of $1-9 \mathrm{wt} \%$. The methanol to oil molar ratio was investigated in the range from $6: 1$ to $18: 1$. The effect of the transesterification reaction time was studied with a time variation of $1-5 \mathrm{~h}$. The optimum operating conditions were determined. Under these conditions, the yield of biodiesel produced was $97.56 \%$ with an ester content of $96.06 \%$. It was shown that the physicochemical properties of biodiesel produced meet the standards.
\end{abstract}

Keywords: biodiesel, $\mathrm{CaO}$ catalyst, transesterification, used cooking oil, waste animal bones.

\section{Introduction}

Biodiesel is one alternative fuel that can replace diesel fuel. Biodiesel can be obtained from a variety of renewable natural resources, such as vegetable oils or animal fats [1]. Biodiesel is produced by reacting vegetable oils or animal fats with alcohols such as methanol and ethanol. Biodiesel has several advantages compared to diesel fuel which is renewable, environmentally friendly, non-toxic, can be degraded biologically, contains very little amount of sulfur and

\footnotetext{
${ }^{1}$ Department of Chemical Engineering, Faculty of Engineering, Diponegoro University,

Jl. Prof. Sudharto, SH, Tembalang, 50275 Semarang, Indonesia

${ }^{2}$ Department of Chemical Engineering, Universitas Muhammadiyah Purwokerto,

Jl. Raya Dukuh Waluh, Kembaran, 53182 Puwokerto, Indonesia

$\triangle$ luqman.buchori@che.undip.ac.id

(c) Buchori L., Anggoro D., Ma'ruf A., 2021
}

polycyclic aromatic hydrocarbon compounds so that it is safe for vehicles, and can be used directly without changing the engine [2-4].

Basically, the biodiesel production process is very simple. Biodiesel is produced through a process called free fatty acid esterification reaction or transesterification reaction of triglycerides with alcohol using a catalyst and from this reaction, fatty acid methyl/ethyl ester and glycerol are produced [5].

Biodiesel can be made from various types of oil, such as palm oil, castor oil, soybean oil, coconut oil, hazelnut oil, jatropha oil, and various vegetable oils containing triglycerides. The used cooking oil is a waste oil derived from the types of cooking oil such as corn oil, vegetable oil, samin oil and so on. The used cooking oil has the potential to be processed into biodiesel because until now the utilization has not been optimal. However, the used cooking oil still contains impurities and has a high level of free fatty acids (FFA $>1 \%$ ) so it must be treated first before being processed into biodiesel [6].

An adsorption using activated charcoal is among the methods to reduce the FFA content in used cooking oil. Salak peel is one of the ingredients that can be used as an activated charcoal. Utilization of a salak peel has not been widely developed, so it needs to be studied more deeply.

The production of biodiesel from the used cooking oil can be conducted through a transesterification reaction. Transesterification reactions can be carried out with homogeneous catalysts, heterogeneous catalysts, and enzyme catalysts. Homogeneous catalysts can use alkaline catalysts $(\mathrm{NaOH}, \mathrm{KOH}$, etc. $)$ or acid catalysts $\left(\mathrm{H}_{2} \mathrm{SO}_{4}, \mathrm{HCl}\right.$, etc.) [7]. Base catalysts require shorter transesterification time, however, homogeneous base catalysts have disadvantages. Homogeneous base catalysts can react with fatty acids to form soap, which will reduce the yield of biodiesel and inhibit the process of separation between glycerol and water [7, 8]. The use of acid catalysts can produce high biodiesel yields but requires a longer reaction time compared to base catalysts. Apart from requiring a long time, the ratio of methanol to the used oil must be large and high temperatures are needed [9]. 
There are so many disadvantages of homogeneous catalysts that the heterogeneous catalysts for biodiesel production were developed. The most widely used heterogeneous catalyst is the $\mathrm{CaO}$ catalyst. $\mathrm{CaO}$ catalyst can be obtained through $\mathrm{CaCO}_{3}$ calcination process. Studies show that $\mathrm{CaO}$ catalysts are mostly made from egg-shells. Wei et al. [10] examined the use of $\mathrm{CaO}$ catalysts in biodiesel production using $\mathrm{CaO}$ from chicken egg-shells and obtained a biodiesel yield of $95 \%$. Chen et al. [11] used $\mathrm{CaO}$ catalyst for biodiesel production using ostrich egg-shells and obtained biodiesel yield of $92.7 \%$. Some researchers also use waste shells such as mollusk [12], Pomacea sp. shell [13], shrimp shell [14], waste mud crab shells and cockle shells [15], oyster shell [16], etc. Utilization of this waste as a raw material in making catalysts will solve the problem of waste and increase economic value.

From many studies on $\mathrm{CaO}$ catalysts for biodiesel production, there are still few studies investigating $\mathrm{CaO}$ catalysts made from waste animal bones [17-19]. Bone is one of the many sources of calcium. The utilization of waste animal bones is environmental-friendly and will be a cost-effective raw material for catalyst production.

The purpose of this study was to investigate the effect of catalyst calcination temperature, the molar ratio of methanol to oil, catalyst loading and the reaction time of transesterification on the yield of biodiesel produced from the used cooking oil using $\mathrm{CaO}$ catalyst derived from waste animal bones. GCMS analysis was carried out to determine fatty acid alkyl esters (FAAE) content in the biodiesel products with the highest yield. The physicochemical properties of biodiesel produced under optimal conditions will be compared with those reported in the literature.

\section{Experimental}

\subsection{Materials}

The raw material used in this study was used cooking oil. The used cooking oil and waste animal bones were obtained from fried chicken restaurant waste in Semarang, Indonesia. Meanwhile, salak peel used as an adsorbent was attained from fruit market waste around Semarang, Indonesia. Methanol (99\%), potassium hydroxide $(\mathrm{KOH})$ and hydrochloric acid $(\mathrm{HCl}, 37 \%)$ were received from Merck.

\subsection{Preparing Activated Charcoal from Salak Peel}

Salak peel from fruit market waste was cleaned with distilled water and dried in an oven. The dried salak peel was crushed and heated in the furnace at $873 \mathrm{~K}$ for $1 \mathrm{~h}$. The resulting product was impregnated with $20 \%$ $\mathrm{KOH}$ solution. After impregnation the product was dried in the oven for overnight at $378 \mathrm{~K}$. Then it was activated in the furnace for $1 \mathrm{~h}$ at $1073 \mathrm{~K}$. The produced activated charcoal was washed using demineralized water $(\mathrm{pH}$ was regulated with $\mathrm{HCl}$ solution until 6-7) and then was dried in the oven overnight.

\subsection{Preparing CaO Catalyst from Waste Animal Bones}

Waste animal bones were washed thoroughly and dried in the oven overnight. Then they were crushed and mashed to a size of 100 mesh. The waste animal bone powder was calcined in the furnace for $3 \mathrm{~h}$. The effect of calcination temperature was investigated by varying the temperatures of $873,973,1073,1173$ and $1273 \mathrm{~K}$.

\subsection{Procedure}

The used cooking oil was pre-treated to reduce the FFA content. Pre-treatment was carried out by adsorbing the used cooking oil with activated charcoal produced from salak peel. The used cooking oil from fried chicken restaurant was first filtered to remove impurities. $250 \mathrm{~g}$ of used cooking oil was heated to $353 \mathrm{~K} .10 \mathrm{~g}$ of activated charcoal adsorbent was added to the oil and stirred at $500 \mathrm{rpm}$ for $80 \mathrm{~min}$. Then the mixture was separated by filtering using Whatman 42 filter paper and the filtrate was used as a raw material for biodiesel production.

The used cooking oil from the pretreatment was reacted with methanol in a three-necked flask. $\mathrm{CaO}$ catalyst from waste animal bones was put into the mixed reactant. The mixture of reactants and catalysts was stirred at a speed of $400 \mathrm{rpm}$ and heated to reach a reaction temperature of $338 \mathrm{~K}$. The effect of methanol to oil molar ratio was studied varying the ratio as 6:1, 9:1, 12:1, 15:1, and 18:1. The effect of catalyst loading was investigated by varying the value as $1,3,5,7$, and $9 \mathrm{wt} \%$ relative to oil. The transesterification process was carried out according to the specified time after the reaction temperature reached $338 \mathrm{~K}$. The reactant mixture was kept under stirring until the transesterification reaction time was complete. The effect of the transesterification time was studied in the range of $1-5 \mathrm{~h}$. The resulting solution was separated from the catalyst and contained unreacted methanol, biodiesel and glycerol. The solution was put into a separating funnel and left overnight. Three layers were formed in the separating funnel. The top layer was unreacted methanol, the middle layer was biodiesel and the bottom layer was glycerol. Biodiesel was analyzed by GCMS. The yields of biodiesel and FAAE were calculated according to Eqs. (1) and (2). 


$$
\begin{gathered}
\text { Yield }_{\text {biodiesel }}=\frac{\text { weight of biodiesel product }}{\text { weight } \text { of used cooking oil }} \cdot 100 \% \\
\text { Yield }_{\text {FAAE }}=\frac{\%_{\mathrm{GC} \text { area FAAE }} \cdot \text { weight of biodiesel product }}{\text { weight of used cooking oil }} \cdot 100 \%
\end{gathered}
$$

\subsection{FFA Analysis}

FFA analysis was carried out to determine the FFA content of used cooking oil, before and after its adsorbtion with the activated charcoal from the salak peel. The FFA analysis was done by titration using $0.1 \mathrm{~N} \mathrm{KOH}$. Free fatty acid was calculated according to Eq. (3).

$$
F F A=\frac{V_{\mathrm{KOH}} \cdot N_{\mathrm{KOH}} \cdot M W_{\text {fatty acid }}}{m_{\text {sample }}} \cdot 100 \%
$$

where $V_{K O H}$ is a volume of titrant, ml; $N_{K O H}$ is a normality of $\mathrm{KOH}, \mathrm{mmol} / \mathrm{ml} ; M W_{\text {fatty acid }}$ is a molecular weight of fatty acid, $\mathrm{mg} / \mathrm{mmol} ; m_{\text {sample }}$ is the weight of the used cooking oil sample, mg.

\section{Results and Discussion}

\subsection{Analysis of FFA Content in the Used Cooking Oil}

FFA content in the used cooking oil was $6.16 \%$. The FFA limit for the transesterification process is $<3 \%$ [20]. Therefore, the FFA value in the used cooking oil must be reduced. This was done by the adsorption method using the activated charcoal from the salak peel. Based on the results of a study conducted by Buchori et al. [21], the FFA adsorption process with the activated charcoal from the salak peel was carried out for $80 \mathrm{~min}$ with $10 \mathrm{~g}$ of the activated charcoal. The adsorption results showed a decrease in FFA value to $0.224 \%$, which meets the requirements for the transesterification process. Therefore, oil is ready to be used for the transesterification process.

\subsection{Effect of Calcination Temperature on the Biodiesel Yield}

The transesterification process is a process where oil and methanol are reacted to produce biodiesel using a catalyst. The catalyst used in this study was $\mathrm{CaO}$. The catalyst was obtained from the calcination of waste animal bones. The calcination temperatures were 873, 973, 1073, 1173 , and $1273 \mathrm{~K}$. The transesterification process was carried out at $338 \mathrm{~K}$ with a reaction time of $2 \mathrm{~h}$. The biodiesel yields are presented in Fig. 1 .

Fig. 1 shows that the biodiesel yield increases with increasing the calcination temperature. This indicates that the catalytic activity of the $\mathrm{CaO}$ catalyst increases when the calcination temperature increases from 873 to $1173 \mathrm{~K}$. The maximum biodiesel yield of $94.64 \%$ was achieved at the calcination temperature of $1173 \mathrm{~K}$. However, further increase in temperature decreases the biodiesel yield from 94.64 to $86.41 \%$. The results of this study are in accordance with the research conducted by Wei et al. [10] on the synthesis of biodiesel using $\mathrm{CaO}$ catalyst from waste egg-shells within the temperature range of 473$1273 \mathrm{~K}$. It was found that the catalyst is very active at the calcination temperature of $1073-1273 \mathrm{~K}$; the biodiesel yield was $97-99 \%$. The research conducted by Nisar et al. [22] showed the same results. They used $\mathrm{CaO}$ catalyst from the waste animal bone with calcination temperatures of $773-1373 \mathrm{~K}$. The results showed that when converting Jatropha oil into biodiesel the catalyst worked optimally at $1173 \mathrm{~K}$; the biodiesel yield was $91.6 \%$. Theoretically, the catalyst will work actively if calcined at its optimum temperature, when more active sites are formed so that it accelerates the occurrence of the reaction and increases the yield of biodiesel [22]. Calcination which is carried out below the optimum temperature does not provide maximum $\mathrm{CaO}$ formation, consequently, the catalytic activity is still low. However, animal bones calcined at high temperatures (exceeding $1273 \mathrm{~K}$ ) increase the sintering effect which ultimately reduces the surface area and basicity of the catalyst and hence leads to the catalyst activity decrease $[22,23]$.

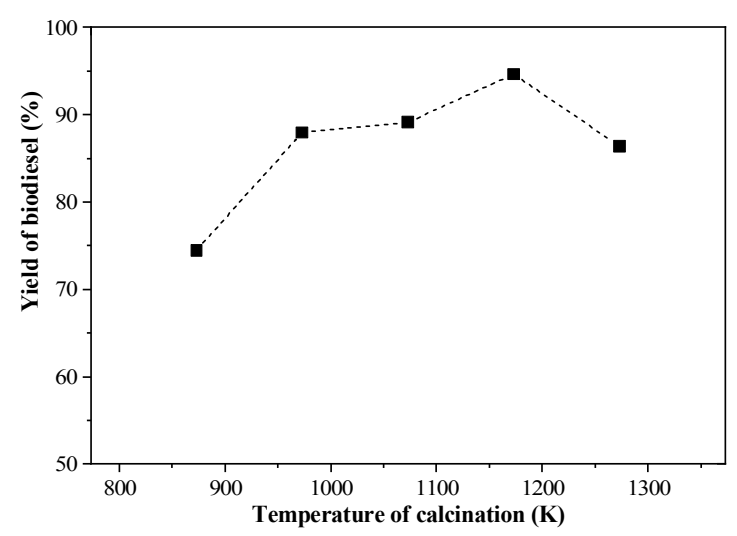

Fig. 1. Effect of calcination temperature on the biodiesel yield $(T=338 \mathrm{~K} ; P=0.1 \mathrm{MPa}$; catalyst loading $=7 \mathrm{wt} \%$, molar ratio of methanol:oil $=15: 1$, reaction time $=2 \mathrm{~h}$ )

\subsection{Effect of Methanol to Oil Molar Ratio on the Biodiesel Yield}

The transesterification reaction was carried out at a temperature of $338 \mathrm{~K}$, a catalyst loading of $7 \%$, and a reaction time of $2 \mathrm{~h}$. The effect of molar ratio of methanol to oil on the biodiesel yield is depicted in Fig. 2. The ratio was varied as $6: 1,9: 1,12: 1,15: 1$, and 18:1.

Fig. 2 shows that the biodiesel yield increases significantly with increasing a molar ratio of methanol to oil and reaches a maximum $(95.54 \%)$ at the ratio of 12:1. 
Further increase in methanol:oil ratio (above 12:1) at first slightly decreases the biodiesel yield to $94.64 \%$ and then significantly decreases it to $90.26 \%$.

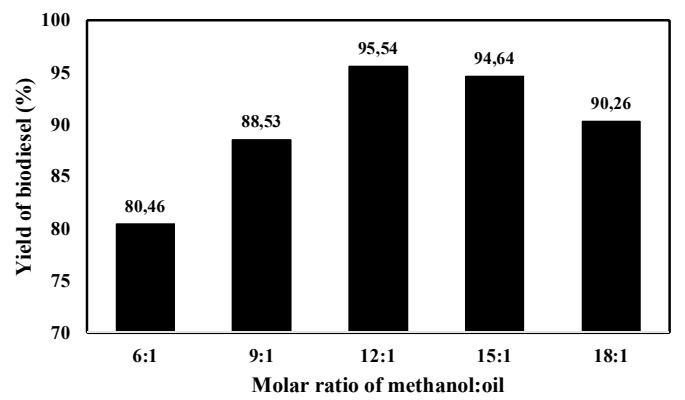

Fig. 2. Effect of methanol:oil molar ratio on the biodiesel yield $(T=338 \mathrm{~K} ; P=0.1 \mathrm{MPa}$; catalyst loading $=7 \mathrm{wt} \%$, reaction time $=2 \mathrm{~h}$ )

The transesterification reaction is a reversible reaction where 1 mole of oil reacts with 3 moles of methanol to produce 3 moles of fatty acid methyl ester and 1 mole of glycerol. Methanol excess is needed to shift the reaction equilibrium towards the product $[5,24]$. When the molar ratio of methanol to oil reaches 12:1 the methanol excess encourages the formation of methoxy species on the $\mathrm{CaO}$ surface so that the reaction equilibrium shifts in the forward direction, thus increasing the yield of biodiesel $[12,19]$. However, further increase in the molar ratio (above 12:1), does not encourage a reaction. The reason is that glycerol produced during the reaction mostly dissolves in methanol excess. This inhibits the reaction of methanol against reactants and catalysts which ultimately complicates the separation of glycerol [12]. High amounts of methanol are also associated with a catalyst deactivation [22]. Therefore, excessive use of methanol can shift the equilibrium in the reverse direction which causes a decrease in biodiesel yield [18, 24, 25].

The results of this study are in line with the research conducted by Viriya-Empikul et al. [12]. They found that the molar ratio of methanol to oil reached optimum at 12:1 using $\mathrm{CaO}$ catalyst derived from the waste shell. Different results were obtained from the research conducted by Farooq et al. [18] and Maneerung et al. [24] who obtained the optimum molar ratio at 15:1. Meanwhile, research conducted by Obadiah et al. [19] showed that the optimum molar ratio was achieved at 18:1 in the production of biodiesel from palm oil. The difference in results is explained by using different type of feedstocks and sample preparation [26].

\subsection{Effect of Catalyst Loading on the Biodiesel Yield}

Biodiesel yield is influenced by a catalyst loading [27]. The effect of catalyst loading on the yield of biodiesel was studied by varying at $1,3,5,7$, and $9 \mathrm{wt} \%$, and the results are shown in Fig. 3.

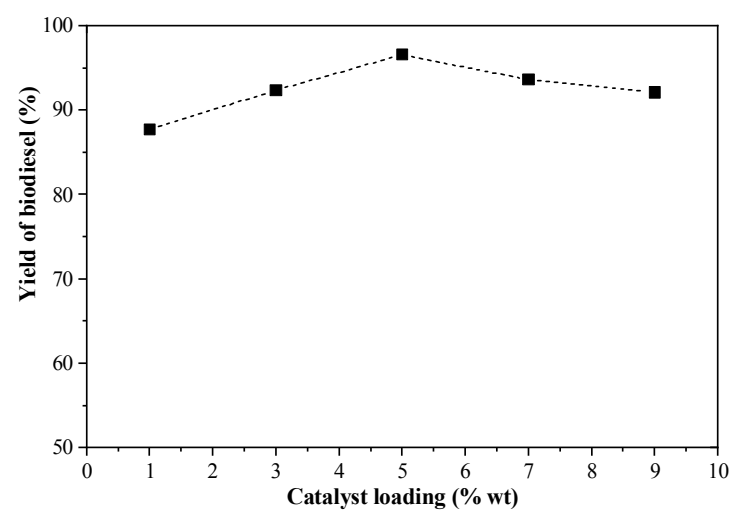

Fig. 3. Effect of catalyst loading on the biodiesel yield $(T=338 \mathrm{~K} ; P=0.1 \mathrm{MPa}$; molar ratio of methanol:oil $=12: 1$, reaction time $=2 \mathrm{~h}$ )

Fig. 3 shows that the biodiesel yield increases with increasing the catalyst loading from 1 to $5 \mathrm{wt} \%$. Biodiesel yield increases from 87.7 to $96.54 \%$ and achieved a maximum of $96.54 \%$ at $5 \mathrm{wt} \%$ of the catalyst. However, the increase in the catalyst loading above $5 \mathrm{wt} \%$ reduces the biodiesel yield from 96.54 to $92.1 \%$. The decrease in the biodiesel yield is due to an increase in the viscosity of the reaction mixture [28]. Increased viscosity inhibits mass transfer in a heterogeneous reaction system. The catalyst excess also causes poor diffusion of reactants in the methanol-oil-catalyst system [24] due to the formation of soap which inhibits the reaction process [18].

The results of this study are in accordance with the research conducted by Farooq et al. [18] who found the optimum amount of catalyst as $5 \mathrm{wt} \%$. Meanwhile, Maneerung et al. [24] obtained the maximum biodiesel yield at a catalyst loading of $7.5 \mathrm{wt} \%$. In this study, the optimum catalyst loading was achieved at $5 \mathrm{wt} \%$.

\subsection{Effect of Reaction Time on the Biodiesel Yield}

Biodiesel yield is also influenced by the reaction time [27]. The effect of reaction time on the yield of biodiesel was investigated by varying at $1,2,3,4$, and $5 \mathrm{~h}$, and the results are depicted in Fig. 4.

Fig. 4 shows that the biodiesel yield increases with increasing the reaction time. The longer the reaction time, the higher the biodiesel yield. This is caused by the fact that the longer transesterification time, more oil reacts with methanol. In addition, the longer the transesterification period provides the opportunity for molecules between reactants to collide with one another. The optimum biodiesel yield of $97.01 \%$ was achieved at the 
reaction time of $3 \mathrm{~h}$. However, with increasing the reaction time, the yield of biodiesel obtained increases slightly and tends to be constant. The increase in reaction time above $3 \mathrm{~h}$ does not produce a significant biodiesel yield. So, the optimum reaction time in this study was $3 \mathrm{~h}$.

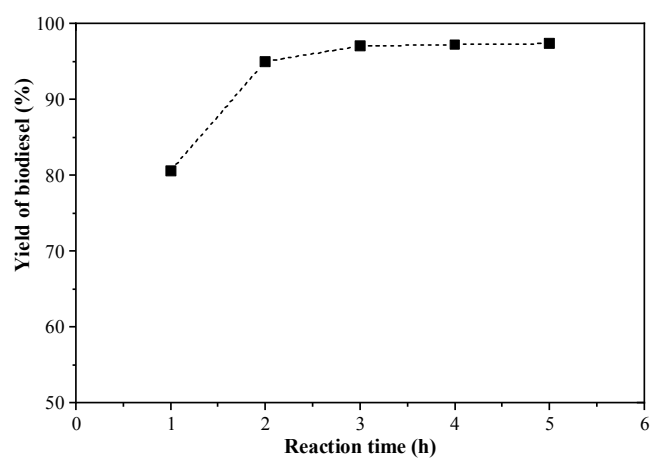

Fig. 4. Effect of reaction time on the biodiesel yield $(T=338 \mathrm{~K} ; P=0.1 \mathrm{MPa}$; catalyst loading $=5 \mathrm{wt} \%$, molar ratio of methanol:oil $=12: 1$ )

The results of this study are consistent with research conducted by Nisar et al. [22] where the reaction time of the transesterification process reaches its optimum at $3 \mathrm{~h}$. In the research conducted by Farooq et al. [18] the optimum reaction time was $4 \mathrm{~h}$. The same results were obtained in research conducted by Obadiah et al. [19]. Different results were obtained by Viriya-Empikul et al. [12] who obtained the optimum reaction time of $2 \mathrm{~h}$.

\subsection{Effect of Reaction Temperature on the Biodiesel Yield}

The reaction temperature greatly influences the reaction rate [29]. The effect of temperature on the yield of biodiesel was studied by varying at $328,333,338,343$ and $348 \mathrm{~K}$, and the results are depicted in Fig. 5.

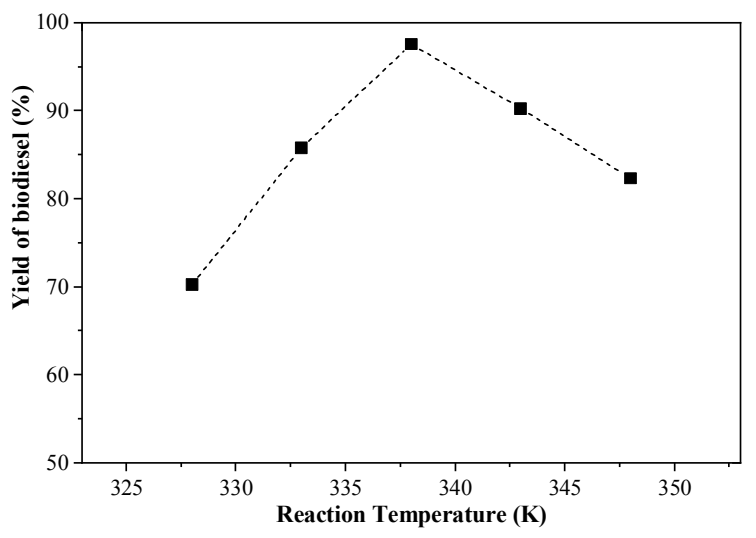

Fig. 5. Effect of reaction temperature on the biodiesel yield

$(P=0.1 \mathrm{MPa}$; catalyst loading $=5 \mathrm{wt} \%$, molar ratio of methanol:oil $=12: 1$, reaction time $=3 \mathrm{~h}$ )
Fig. 5 shows that the biodiesel yield increases with increasing reaction temperature and achieves optimal results at $338 \mathrm{~K}(97.56 \%)$. An increase in reaction temperature above $338 \mathrm{~K}$ leads to the reduction in biodiesel yield. Transesterification reaction is an endothermic reaction, so the increase in reaction temperature accelerates the movement of reactant molecules in the system. This fact increases collisions between reactant molecules which ultimately accelerates the reaction rate and produces high yields of biodiesel products $[18,29,30]$. At high temperatures, triglycerides can dissolve well in methanol so that it forms a single phase resulting in the increase in product [29]. However, when the reaction temperature is raised above the optimum temperature $(338 \mathrm{~K})$, there is evaporation of methanol and some side reactions such as oil polymerization cause a decrease in biodiesel products yield [30].

\subsection{Characterization of Catalyst}

Catalyst characterization was performed by X-Ray Diffraction (XRD) analysis using Shimadzu XRD-7000. The diffraction patterns were analyzed in the $2 \theta$ range from $10^{\circ}$ to $90^{\circ}$ with a scanning speed of $4^{\circ}$ per min. XRD analysis was performed at the optimum calcination temperature of $1173 \mathrm{~K}$, before and after calcination. The results are presented in Fig. 6.

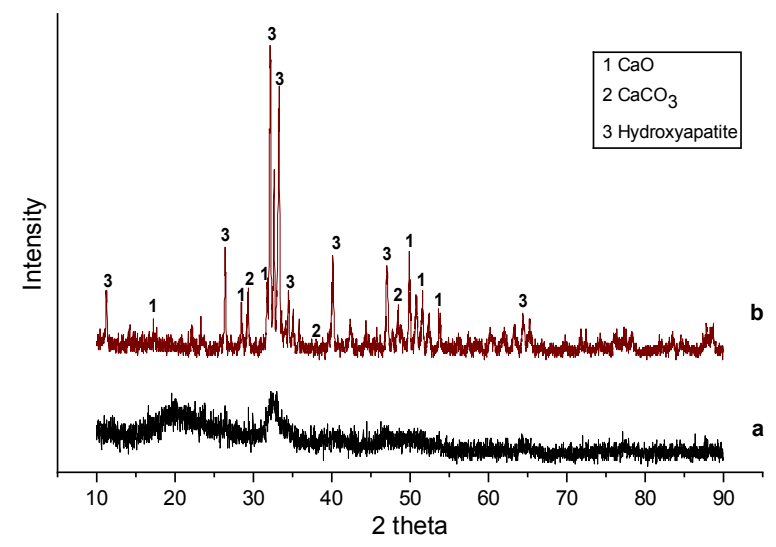

Fig. 6. XRD patterns of the catalyst before calcination (a) and after calcination at $1173 \mathrm{~K}$ (b)

Fig. 6 shows that the peak intensity increases after calcination, and therefore crystallinity increases as well. The peaks typical of $\mathrm{CaO}$ phase in the catalyst are $17.69^{\circ}$, $28.68^{\circ}, 32.19^{\circ}, 50.79^{\circ}, 52.43^{\circ}$, and $53.71^{\circ}$ (JCPDS File No. 37-1497). The presence of hydroxyapatite is marked with peaks at $10.97^{\circ}, 25.85^{\circ}, 32.54^{\circ}, 33.68^{\circ}, 35.11^{\circ}$, $39.85^{\circ}, 46.75^{\circ}$, and $65.04^{\circ}$. The peaks at $29.34^{\circ}, 39.69^{\circ}$, and $48.45^{\circ}$ are attributed to the $\mathrm{CaCO}_{3}$ phase [31]. 


\subsection{The Results of FAAE Identification in Biodiesel Products}

The best results from this study were then analyzed by GCMS to determine the FAAE content in biodiesel products. GCMS analysis was carried out for biodiesel obtained at the calcination temperature of $1173 \mathrm{~K}$, methanol:oil molar ratio of $12: 1$, reaction time of $3 \mathrm{~h}$ and catalyst loading of $5 \mathrm{wt} \%$. The results of the GCMS analysis are presented in Fig. 7 and Table 1.

As can be seen from Fig. 7 and Table 1, there are 15 peaks (components) in the biodiesel products. However, there are only 9 peaks that represent alkyl esters. The of FAAE content in biodiesel products is $96.06 \%$. Based on Eq. (3), the FAAE yield obtained is $93.72 \%$.

Balakrishnan et al. [27] studied the synthesis of biodiesel with the used cooking oil as a raw material using a $\mathrm{Ba} / \mathrm{CaO}(3 \mathrm{wt} \%)$ catalyst for $3 \mathrm{~h}$ at $338 \mathrm{~K}$ with a mole ratio of methanol to oil 9:1. They reported the methyl ester yield was found to be $88 \%$. Meanwhile, Farooq et al. [18] studied biodiesel production with the waste cooking oil as a raw material using $\mathrm{CaO}(5 \mathrm{wt} \%)$ derived from the chicken bone. They obtained a biodiesel yield of $89.33 \%$ with $97.91 \%$ of methyl ester. The transesterification process was carried out for $4 \mathrm{~h}$, at $338 \mathrm{~K}$ and the methanol:oil ratio of 15:1. Nisar et al. [22] obtained biodiesel from Jatropha oil using animal bones modified with potassium hydroxide $(\mathrm{KOH})$ as a catalyst with the yield of fatty acid methyl ester (FAME) of $96.1 \%$ at the reaction temperature of $343 \mathrm{~K}$, reaction time of $3 \mathrm{~h}$, methanol/oil molar ratio of $9: 1$, calcination temperature of $1173 \mathrm{~K}$ and catalyst concentration of $6.0 \mathrm{wt} \%$.

In this study, we obtained the biodiesel yield of $97.56 \%$ with the FAAE content of $96.06 \%$. This fact indicates that this research can produce high biodiesel yields with high FAAE content. The results of this study prove that both waste cooking oil and waste animal bone can be used for biodiesel synthesis with good results.

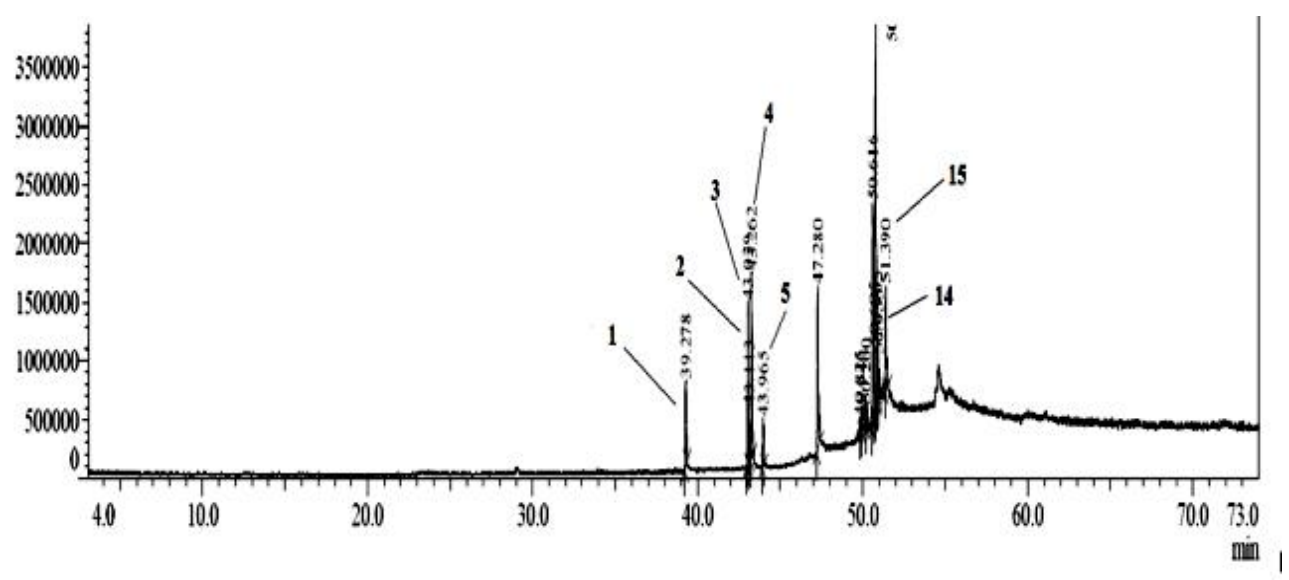

Fig. 7. The results of GCMS analysis of biodiesel products

Composition of biodiesel components

\begin{tabular}{|c|c|c|c|}
\hline Peak & R Time & Composition, $\%$ & Name \\
\hline 1 & 39.278 & 4.52 & Hexadecanoic acid, methyl ester (CAS) \\
\hline 2 & 43.039 & 8.18 & 9,12-Octadecadienoic acid, methyl ester, (E,E)-(CAS) \\
\hline 3 & 43.113 & 9.68 & 9,12,15-Octadecatrienoic acid, methyl ester, (Z,Z,Z)-(CAS) \\
\hline 4 & 43.262 & 10.01 & 9-Octadecenoic acid (Z)-, methyl ester (CAS) \\
\hline 5 & 43.965 & 1.33 & Octadecanoic acid, methyl ester (CAS) \\
\hline 6 & 47.280 & 11.32 & Hexadecanoic acid, 2-hydroxy-1,3-propanediyl ester (CAS) \\
\hline 7 & 49.825 & 4.45 & 9-Hexadecenoic acid, methyl ester, (Z)-(CAS) \\
\hline 8 & 49.940 & 0.24 & O-Acetyljervine \\
\hline 9 & 50.200 & 0.99 & DI-(9-OCTADEuinoline \\
\hline 10 & 50.616 & 1.09 & trans-Caryophyllene \\
\hline 11 & 50.695 & 0.39 & Octadecanoic acid, methyl ester (CAS) \\
\hline 12 & 50.786 & 39.41 & 3-Acetoxy-p-menthan-1-ol \\
\hline 13 & 50.905 & 0.54 & 1,5-Naphthalenediol, decahydro- (CAS) \\
\hline 14 & 50.955 & 0.69 & Octadecanoic acid, 2-hydroxy-1,3-propanediyl ester (CAS) \\
\hline 15 & 51.390 & 7.16 &
\end{tabular}


Physicochemical properties of the biodiesel products under optimal conditions

\begin{tabular}{|c|c|c|c|c|}
\hline Properties & Units & Standard & Method & Experimental values \\
\hline Density at $25^{\circ} \mathrm{C}$ & $\mathrm{g} / \mathrm{cm}^{3}$ & $0.860-0.900$ & EN 14214 & 0.876 \\
\hline Kinematic viscosity at $40^{\circ} \mathrm{C}$ & $\mathrm{mm}^{2} / \mathrm{s}$ & $1.9-6.0$ & ASTM D-6751 & 4.566 \\
\hline Acid number & $\mathrm{mg} \mathrm{KOH} / \mathrm{g}$ & $\leq 0.5$ & ASTM D-6751 & 0.42 \\
\hline Ester content & $\%$ & $>96.5$ & ASTM D-6751 & 96.06 \\
\hline Cetane number & - & min. 47 & ASTM D-6751 & 51.2 \\
\hline Heating value & $\mathrm{MJ} / \mathrm{kg}$ & 39.72 & ASTM D-240 & 43.86 \\
\hline
\end{tabular}

\subsection{Physicochemical Properties of the Biodiesel Products}

The physicochemical properties of biodiesel were analyzed under optimum conditions and then compared with those reported in the literature (Table 2).

Table 2 shows that the physicochemical properties of the produced biodiesel meet ASTM and EN standards. Only the content of esters is slightly below standard.

The heating value states the amount of heat produced from the combustion of a certain amount of fuel with air/oxygen. The greater the heating value, the less fuel is needed to produce certain amount of heat. Thus, the greater the heating value, the more efficient fuel will be. In our case the heating value was found to be $43.86 \mathrm{MJ} / \mathrm{kg}$ which is higher than standard diesel fuel value which is equal to $39.72 \mathrm{MJ} / \mathrm{kg}$.

\section{Conclusions}

In the current research, the waste animal bone was successfully used as a heterogeneous catalyst in the synthesis of biodiesel using the used cooking oil as a feedstock. The results showed that the biodiesel synthesis was influenced by many factors including a calcination temperature, the molar ratio of methanol to oil, catalyst loading, and reaction time. The highest yield of biodiesel was achieved under optimum reaction conditions, namely calcination temperature of $1173 \mathrm{~K}$, the methanol:oil molar ratio of $12: 1$, catalyst loading of $5 \mathrm{wt} \%$ and reaction time of $3 \mathrm{~h}$. Under these optimum conditions a biodiesel yield of $97.56 \%$ was obtained with an ester content of $96.06 \%$. Biodiesel produced under optimum conditions was characterized and its physicochemical properties were compared with the standards reported in the literature. The results indicate that the physicochemical properties of the biodiesel produced fulfill the standards. This shows that the catalyst from waste animal bone is a potential, economical and environmentally friendly catalyst for biodiesel production.

\section{Acknowledgements}

The author would like to thank the financial assistance provided by the Faculty of Engineering, Diponegoro University, Semarang, Indonesia.

\section{References}

[1] Abdullah N., Hasan S., Yusoff N.: Int. J. Mater. Sci. Eng., 2013, 1, 94. https://doi.org/10.12720/ijmse.1.2.94-99

[2] Buchori L., Istadi I., Purwanto P.: Sci. Study Res. Chem. Chem. Eng. Biotechnol. Food Ind., 2017, 18, 303. https://pubs.ub.ro/? pg-revues\&rev $=\mathrm{cscc} 6 \&$ num $=201703 \&$ vol $=3 \&$ aid $=4619$

[3] Tabatabaei M., Aghbashlo M., Dehhaghi M. et al.: Prog. Energy Combust. Sci., 2019, 74, 239.

https://doi.org/10.1016/j.pecs.2019.06.001

[4] Talebian-Kiakalaieh A., Amin N., Mazaheri H.: Appl. Energy, 2013, 104, 683. https://doi.org/10.1016/j.apenergy.2012.11.061 [5] Buchori L., Istadi I., Purwanto P.: Bull. Chem. React. Eng. Catal., 2016, 11, 406. https://doi.org/10.9767/bcrec.11.3.490.406-430

[6] Devaraj K., Veerasamy M., Aathika S. et al.: J. Clean. Prod., 2019, 225, 18. https://doi.org/10.1016/j.jclepro.2019.03.244

[7] Lee S., Wong Y., Tan Y. et al.: Energy Convers. Manag., 2015, 93, 282. https://doi.org/10.1016/j.enconman.2014.12.067

[8] Lam M., Lee K., Mohamed A.: Biotechnol. Adv., 2010, 28, 500. https://doi.org/10.1016/j.biotechadv.2010.03.002

[9] Lee D., Park Y., Lee K.: Catal. Surv. Asia, 2009, 13, 63.

https://doi.org/10.1007/s10563-009-9068-6

[10] Wei Z., Xu C., Li B.: Bioresour. Technol., 2009, 100, 2883. https://doi.org/10.1016/j.biortech.2008.12.039

[11] Chen G., Shan R., Shi J. et al.: Bioresour. Technol., 2014, 171, 428. https://doi.org/10.1016/j.biortech.2014.08.102

[12] Viriya-Empikul N., Krasae P., Puttasawat B. et al.: Bioresour. Technol., 2010, 101, 3765.

https://doi.org/10.1016/j.biortech.2009.12.079

[13] Margaretha Y., Prastyo H., Ayucitra A. et al.: Int. J. Energy Environ. Eng., 2012, 3, 1. https://doi.org/10.1186/2251-6832-3-33

[14] Yang L., Zhang A., Zheng X.: Energy Fuel., 2009, 23, 3859. https://oi.org/10.1021/ef900273y

[15] Boey P., Ganesan S., Maniam G. et al.: Catal. Today, 2012, 190, 117. https://doi.org/10.1016/j.cattod.2011.11.027

[16] Nakatani N., Takamori H., Takeda K. et al.: Bioresour. Technol., 2009, 100, 1510. https://doi.org/10.1016/j.biortech.2008.09.007 [17] Corro G., Sánchez N., Pal U. et al.: Waste Manag., 2016, 47, 105. https://doi.org/10.1016/j.wasman.2015.02.001

[18] Farooq M., Ramli A., Naeem A.: Renew. Energy, 2015, 76, 362. https://doi.org/10.1016/j.renene.2014.11.042

[19] Obadiah A., Swaroopa G., Kumar S. et al.: Bioresour. Technol. 
2012, 116, 512. https://doi.org/10.1016/j.biortech.2012.03.112 [20] Atadashi I., Aroua M., Aziz A. et al.: Renew. Sustain. Energy Rev., 2012, 16, 3275. https://doi.org/10.1016/j.rser.2012.02.063 [21] Buchori L., Ubay D., Syahidah K.: Reaktor, 2018, 18, 149. https://doi.org/10.14710/reaktor.18.03.149-154

[22] Nisar J., Razaq R., Farooq M. et al.: Renew. Energy, 2017, 101, 111. https://doi.org/10.1016/j.renene.2016.08.048

[23] Yang Z., Xie W.: Fuel Process. Technol., 2007, 88, 631. https://doi.org/10.1016/j.fuproc.2007.02.006

[24] Maneerung T., Kawi S., Dai Y. et al.: Energy Convers. Manag., 2016, 123, 487. https://doi.org/10.1016/j.enconman.2016.06.071

[25] Lim B., Maniam G., Hamid S.: Eur. J. Sci. Res., 2009, 33, 347.

[26] Ayetor G., Sunnu A., Parbey J.: Alexandria Eng. J., 2015, 54,

1285. https://doi.org/10.1016/j.aej.2015.09.011

[27] Balakrishnan K., Olutoye M., Hameed B.: Bioresour. Technol., 2013, 128, 788. https://doi.org/10.1016/j.biortech.2012.10.023

[28] Xie W., Zhao L.: Energy Convers. Manag., 2014, 79, 34. https://doi.org/10.1016/j.enconman.2013.11.041

[29] Thinnakorn K., Tscheikuna J.: Appl. Catal. A, 2014, 476, 26. https://doi.org/10.1016/j.apcata.2014.02.016

[30] Yan F., Yuan Z., Lu P. et al.: Renew. Energy, 2011, 36, 2026. https://doi.org/10.1016/j.renene.2010.10.032

[31] Lesbani A., Tamba P., Mohadi R. et al.: Indones. J. Chem., 2013, 13, 176. https://doi.org/10.22146/ijc.21302

\section{СИНТЕЗ БІОДИЗЕЛЯ 3 ВИКОРИСТАНОЇ КУЛІНАРНОЇ ОЛІЇ ЗА УЧАСТЮ КАТАЛІЗАТОРА СаО ОДЕРЖАНОГО 3 ВІДХОДІВ КОСТЕЙ ТВАРИН}

Анотація. Проведено синтез біодизеля з використаної кулінарної олії з каталізатором СаО одержсаним з відходів кісток тварин. За допомогою активованого вугілля, одержаного із шкірки салаку, в процесі адсорбування знижено вміст вільних жирних кислот (FFA) у використаному кулінарному маслі. Синтез біодизеля проводили внаслідок переестерифікаиіі з використанням каталізатора СаО. Каталізатор СаО отримували з відходів кісток тварин, прожарених у печі. Вплив чинників на вихід біодизеля досліджено в наступних інтервалах: температура прожарювання (873-1273 K), завантаження каталізатора (1-9 мас.\%), мольне співвідношення метанолу до олії (від 6:1 до 18:1) і час переестерифікачії (1-5 год) і встановлено оптимальні умови. За чих умов вихід отриманого біодизеля становив 97,56\% при вмісті естерів 96,06\%. Показано, щчо фізико-хімічні властивості одержсаного біодизеля відповідають стандартам.

Ключові слова: біодизель, каталізатор СаО, переестерифікачія, використане олія, відходи кісток тварин. 